\title{
Altruistic Leadership and Organizational Citizenship Behavior: Leader-Member Exchange Mediation Role
}

\author{
Bismil One Chanko ${ }^{a, *}$, Adi Rahmat ${ }^{b, *}$ \\ ${ }^{a}$ Magister of Management, Graduate Program, Universitas Lancang Kuning, Indonesia.
}

\begin{tabular}{|c|c|}
\hline ABSTRACT & ARTICLE HISTORY \\
\hline $\begin{array}{l}\text { This study aims to investigate and explain theoretically and empirically the } \\
\text { impact of altruistic leadership on employee OCB. Furthermore, this study } \\
\text { aims to investigate the psychological mechanisms that influence the } \\
\text { relationship. Explanatory studies are used in this study. Using quantitative } \\
\text { methods to test hypotheses empirically. This study seeks to obtain data by } \\
\text { sending a questionnaire to one of the Regional Apparatus Units (SKPD) in } \\
\text { the Pekanbaru city, namely the Pekanbaru City Civil Service Police Unit by } \\
\text { utilizing self-administered questionnaire. From the results of questionnaires } \\
\text { that have been distributed to } 203 \text { members of the Pekanbaru City Civil } \\
\text { Service Police Unit, it can be obtained an overview of gender, age, last } \\
\text { education, length of service, and achievements. These results are expected } \\
\text { to provide innovation and information for leaders to improve relations with } \\
\text { subordinates with the aim of advancing the Pekanbaru City Civil Service } \\
\text { Police Unit as an enforcer of Regional Regulations and Regional Head } \\
\text { Regulations. }\end{array}$ & $\begin{array}{l}\text { Accepted: December 31, } 2021 \\
\text { KEYwORDS } \\
\text { Altruistic Leadership, } \\
\text { Organizational Citizenship } \\
\text { Behavior and Leader-Member } \\
\text { Exchange }\end{array}$ \\
\hline
\end{tabular}

\section{Introduction}

Organizations today recognize that knowledge is a valuable resource to achieve organizational success. Thus, they try to find the best way to manage knowledge effectively. Knowledge exchange behavior, such as knowledge sharing is a key component in knowledge management systems and one of the popular topics in the field of knowledge management because it is considered the productive knowledge behavior of organizational members. A number of studies have tried to investigate the factors that encourage knowledge sharing, including environmental and individual factors. Despite the broad understanding of how to promote knowledge sharing, unproductive knowledge management practices persist among knowledge jobs.

Leadership is sometimes defined as the exercise of authority and decision making. Leadership is also defined as an initiative to act that produces a consistent pattern in order to find a way to solve a common problem. Furthermore, Thoha (2003) formulated that leadership is an activity to influence people so that they are directed to achieve organizational goals. Therefore, the success of an organization in achieving its goals or achieving good performance is largely determined from the condition of the organization itself. From the concept described by Davis (2009), leadership is the main factor influencing organizational "CORRESPONDING AUTHOR. Email:adirahmat@unilak.ac.id. 
performance. Leaders can oversee the activities of other people or members of the organization and are responsible for achieving organizational goals. In other words, the leadership entity in an organization plays a dominant role in carrying out all of its functions.

This shows that the leadership aspect is considered important in regulating, influencing subordinates in order to achieve organizational goals. Rivai and Mulyadi (2003:3) summarize several definitions of leadership as follows: (1) The art of influencing and directing people by means of obedience, trust, respect, and enthusiastic cooperation in achieving common goals; (2) The process of influencing or setting an example from leaders to followers in an effort to achieve organizational goals; (3) The ability to influence a group to achieve organizational goals; (4) The ability to influence, inspire and direct the actions of a person or group to achieve the expected goals. There is a phenomenon related to leadership in that not all subordinates are satisfied and do not want to carry out their leader's instructions. From the initial observations according to employees, "the role of the leader is very important for them, sometimes they lack sympathy if they have a bad leader or even sometimes we also skip work because the work atmosphere is not good with unsympathetic leadership". This can happen because the leadership does not often communicate directly so that they cannot establish a good working relationship with employees. Abdillah (2020) defines altruistic behavior as "a tendency of a person to take voluntary actions intended to help others by sacrificing personal interests without expecting rewards"

Performance is also influenced by competence. Basically, all employees in the Civil Service Police Unit on average have competence in working, it's just that the availability of existing employees with those needed is still lacking in the existing number. Often an employee does work that is not his job. Competence includes the knowledge and abilities possessed by employees (employees), which is at least reflected in their level of education. To be able to move employees to work more effectively, it is necessary to develop and utilize existing human resources in order to become employees who have high loyalty and adequate quality and abilities according to the fields and skills they have so that they can work effectively and efficiently. (Davis, in Mangkunegara, 2011:13).

Besides that, the success or failure of an employee is determined by whether or not the competences possessed by the field of work, which are commonly referred to as right man in the right job. The problem of right man in the right job ini increasingly widespread in almost all offices in Indonesia since the implementation of regional autonomy. Various kinds of things are the cause, ranging from limited human resources to the problem of an employee's proximity to policy makers.

Leaders who do not expect rewards by putting aside personal interests for the realization of the goals of an organization are good leaders. The relationship between leadership and employees is needed to achieve this goal. It would be nice for leaders to be able to exchange ideas with employees regardless of status for the realization of the organization's goals. That way the leader can directly assess what problems are happening to his employees and find solutions to fix these problems. 


\section{Theoretical support}

\section{Social Exchange Theory}

Social Exchange Theory--SET is based on the idea that people view their relationships in an economic context and they calculate the costs and compare them to the rewards gained by continuing the relationship. Cost is an element of a relationship that has negative value for a person, while rewards are elements in a relationship that have a positive value (West \& Turner, 2009 : 216). The Social Exchange Theory point of view holds that people calculate the overall value of a relationship by subtracting its sacrifices from the rewards it receives (Monge \& Contactor, 2003). Social Exchange Theory predicts that the value of worth of a relationship affects the final outcome or whether people will continue the relationship or end it. A positive relationship can usually be expected to last, whereas a negative relationship may end (West Turner, 2009 : 217). The Social Exchange Theory point of view holds that people calculate the overall value of a relationship by subtracting its sacrifices from the rewards it receives (Monge \& Contactor, 2003). Social Exchange Theory predicts that the worth of a relationship affects the outcome or whether people will continue the relationship or end it. A positive relationship can usually be expected to last, whereas a negative relationship may end (West Turner, 2009 : 217).

\section{Leadership}

The important value of leadership in the organization plays a very important role in organizational management. Leadership is needed by humans because of certain limitations in humans. This is where the need to lead and be led comes from. Based on Sutrisno (2010:213) "Leadership is a process of one's activities to move others by leading, guiding, influencing others to do something in order to achieve the expected results". The broad definition of leadership includes "the process of influencing in setting organizational goals, motivating the behavior of followers to achieve goals, influencing to improve the group and its culture". It also affects the interpretation of the events of his followers, organizing and activities to achieve goals, maintaining cooperative relationships and work groups, obtaining support and cooperation from people outside the group or organization. (Rivai and Mulyadi, 2013:2). According to Terry George R translated by Kartini Kartono (2011:57) Leadership is the activity of influencing people so that they like to try to achieve group goals. In addition, according to Miftah Thoha (2011:9) leadership is an activity to influence the behavior of others, or the art of influencing human behavior both individually and in groups.

\section{Organizational Citizenship Behavior (OCB)}

Organ (2006) define organizational citizenship behavior (OCB) as individual behavior that is free, not directly or explicitly related to the system reward and can improve the effective functioning of the organization. According to Organ, Podsakoff, and Mackenzie (2006) OCB is a form of extra- role behavior which increases the bonding effect among organizational members. Bonds between each member will emerge from positive emotions, then positive 
emotions can generate union members for general approval rather than conflict. Approval of members in the organization makes conflicts can be resolved properly. OCB It is also a behavior that is freely chosen by the individual. Greenberg and Robert (2003) states that OCB is an action taken by members of the organization that exceeds the formal provisions of the organization's work. Podsakoff, Bachrach, and Bendoly (2001) defines OCB as a form of behavior that is an individual choice, not directly or explicitly recognized from the organization's formal reward system but in aggregate increases organizational effectiveness. According to Robbins and Judge (2008) OCB is an employee's work behavior in the organization that is carried out voluntarily outside the job description that has been set to improve the progress of organizational performance. Based on various opinions that have been put forward by several experts, it can be concluded that OCB is a voluntary behavior outside of the tasks required by the company, so that employees will work beyond the company's expectations.

\section{Leader-Member Exchange (LMX)}

Leader member exchange (LMX) or exchange of leader members is a dimension that must be owned by an organization in order to create good communication, so that personal relationships between leaders and their subordinates can be harmonious. (Zakiy, 2015). The leader member exchange theory focuses on dyadic relationships, namely the relationship between a leader and each of his personal subordinates and each relationship between a pair of leader-members has a different quality. (Putri dan Nurul, 2010).

LMX is a theory that supports leaders create in-group and out-group; subordinates with status in- group will get a high level of performance; less turnover; and greater job satisfaction (Robbins and Judge, 2013: 377). In a Leader member exchange (LMX) or exchange of leader members is a dimension that must be owned by an organization in order to create good communication, so that personal relationships between leaders and their subordinates can be harmonious (Zakiy, 2015). Teory of leader member exchange focus on dyadic relationship, namely the relationship between a leader and every personal subordinate and every relationship between a leader-member couple it has a different quality (Putri and Nurul, 2010). LMX is a theory that supports leaders create in-group and out-group; subordinates with in-group status will get a high level of performance; less turnover; and greater job satisfaction (Robbins and Judge, 2013: 377).

\section{Research method}

\section{Explanatory Study Research}

Explanatory studies are used in this study. Explanatory study is a study that aims to explain why a phenomenon occurs. In addition, this type of research also seeks to build, expand, elaborate or test theory (Neuman, 2011). The current study aims to elucidate the mechanisms underlying the relationship between altruistic leadership and OCB based on social exchange theory. This study aims to obtain data by sending a questionnaire to one of the Regional 
Apparatus Unit (SKPD) in the Pekanbaru city, namely Police Unit in the Pekanbaru city by using self-administered questionnaire (Bourque \& Fielder, 2003). The distribution of the questionnaire will be carried out by convenience sampling method (Fink, 2003).

\section{Results}

\section{Distribution of Respondents by Gender}

It is known that of the 203 respondents who are members of Police Unit in the Pekanbaru city, grouped by gender. For respondents with male sex as many as 154 people (75.8\%) and female sex as many as 49 people (24.2\%). Thus, it can be seen that proportionally the number of male respondents is more than female with a ratio of $75.8 \%$ and $24.2 \%$ for women.

\section{Distribution of Respondents by Age}

It is known that the majority of respondents are in the age category between $>30$ years with a total of 67 respondents or equal to (33\%). Age category 20-25 years with a total of 65 respondents or equal to (32\%). Age category 26-30 years with a total of 62 respondents or equal to $(30.5 \%)$. While the least respondents are at the age level $<20$ years, namely only 9 respondents or equal to $(4.5 \%)$.

\section{Distribution of Respondents by Level of Education}

It is known that the majority of respondents are members of Police Unit in the Pekanbaru city at the high school education level with a total of 138 respondents or $67.9 \%$. While the second respondent at the undergraduate level of education with a total of 61 respondents or $30 \%$. Then the third respondent at the Diploma level as many as 3 respondents or $2 \%$. Then the least respondents were at the postgraduate education level, namely 1 respondent or $0.1 \%$.

\section{Distribution of Respondents by Length of Work}

It is known that the most respondents in the category of working years $>7$ years with a total of 83 respondents or $40.8 \%$. The category of working length of time is 1-3 years with a total of 60 respondents or $29.5 \%$. Then the category of length of work $<1$ year with a total of 37 respondents or $18.2 \%$. While the least respondents are in the category of working years of 4 years - 7 years, namely only 23 respondents or $11.5 \%$.

\section{Distribution of Respondents by Achievement Level During Work}

It can be seen that the majority of respondents are in the never before category with a total of 142 respondents or $69.9 \%$. Meanwhile, the least respondents were in the never category, which was only 61 respondents or $30.1 \%$. 
Reliability Calculation Results

Table 1. Reliability Calculation Results

\begin{tabular}{llll}
\hline Reliability & Altruis & LMX & OCB \\
\hline Composite reliability & 0.871 & 0.957 & 0.919 \\
Category & High & Very high & Very high \\
Cronbach's alpha & 0.801 & 0.949 & 0.892 \\
Category & High & Very high & Very high \\
\hline source: Primary Data, processed(2021) & &
\end{tabular}

Based on table 1 shows the reliability value as measured by composite reliability and Croncbach's alpha. In the composite reliability value, the reliability value of the Altruistic variable is 0.871 and the moderating model for the Leader Member Excange variable is 0.957 with the OCB variable of 0.919 including the very high reliability category. The composite reliability value of the altruistic variable is 0.801 , including the high reliability category. While the composite reliability value of the Leader Member Excange variable is 0.949 including the very high reliability category and the composite reliability value of the OCB variable is 0.892 which is the high category.

The first hypothesis (H1) predicts that altruistic leadership has a positive effect on leadermember exchange. The results show that this hypothesis is statistically supported $(\beta=-0,51, p$ $<0.001)$. The table shows that the altruistic leadership variable is positively related to the Leader-member exchange.

The second hypothesis (H2) predicts that Leader-member exchange has a negative effect on organizational citizenship behavior. The results show that this hypothesis is statistically supported $(\beta=-0416, p<0.001)$. The table shows that the Leader-member exchange variable negatively affects the Organizational citizenship behavior variable.

Furthermore, the third hypothesis (H3) predicts that Leader-member exchange mediates the influence of altruistic leadership on organizational citizenship behavior. The results show that this hypothesis is statistically supported $(\beta=-0,198, p<0.001)$. The table shows that the Leader-member exchange variable significantly mediates the effect of altruistic leadership on subordinates' silence behavior. The table also shows that when the mediating variable (Organizational citizenship behavior) is included in the model, the value of the influence of altruistic leadership on organizational citizenship behavior decreases from -0.25 to -0.059 and is not significant. These results indicate that the Leader-member exchange variable in this study fully mediates the influence of altruistic leadership on organizational citizenship behavior.

\section{Discussions}

\section{Organizational Citizenship Behavior (OCB)}

According to Robbins and Judge (2008) OCB is an employee's work behavior in an organization that is carried out voluntarily outside the job description that has been set to improve the progress of organizational performance. Respondents were asked to answer the 
questions on a Likert scale with 7 points ranging from 1 ("strongly disagree") to 7 ("strongly agree"). A high score (7) indicates a high perception of subordinates on employee behavior. On the other hand, a low score (1) indicates a low subordinate's perception of employee behavior.

\section{Leader-Member Exchange (LMX)}

The leader member exchange theory focuses on dyadic relationships, namely the relationship between a leader and each of his personal subordinates and each relationship between a pair of leader-members has a different quality (Putri and Nurul, 2010). Respondents were asked to answer the questions on a Likert scale with 7 points ranging from 1 ("strongly disagree") to 7 ("strongly agree"). A high score (7) indicates a high perception of subordinates on employee behavior. On the other hand, a low score (1) indicates a low subordinate's perception of employee behavior.

\section{Test result Common Method Variance (CMV)}

This study collects data at the same time and source. Therefore, there is a possibility that the data still has the potential to generate results common method variance (CMV) (Podsakoff et al., 2003, 2012). To ensure that general method bias can be controlled, this study uses full collinearity variance inflation factors (VIFs) to evaluate whether the data in the study have CMV problems or not (Kock, 2015).

Tabel 2. Test Result Full Collinearity VIFs

\begin{tabular}{ccc}
\hline Altruistic Leadership & Leader-member exchange & Organizational Citizenship Behavior \\
\hline 1,31 & 1,5 & 1,192 \\
\hline
\end{tabular}

The results of table 2 show that each variable has a value of full collinearity VIFs lower than 3.3. Thus, the data in this study do not have the potential to produce common method variance (CMV) (Kock, 2015).

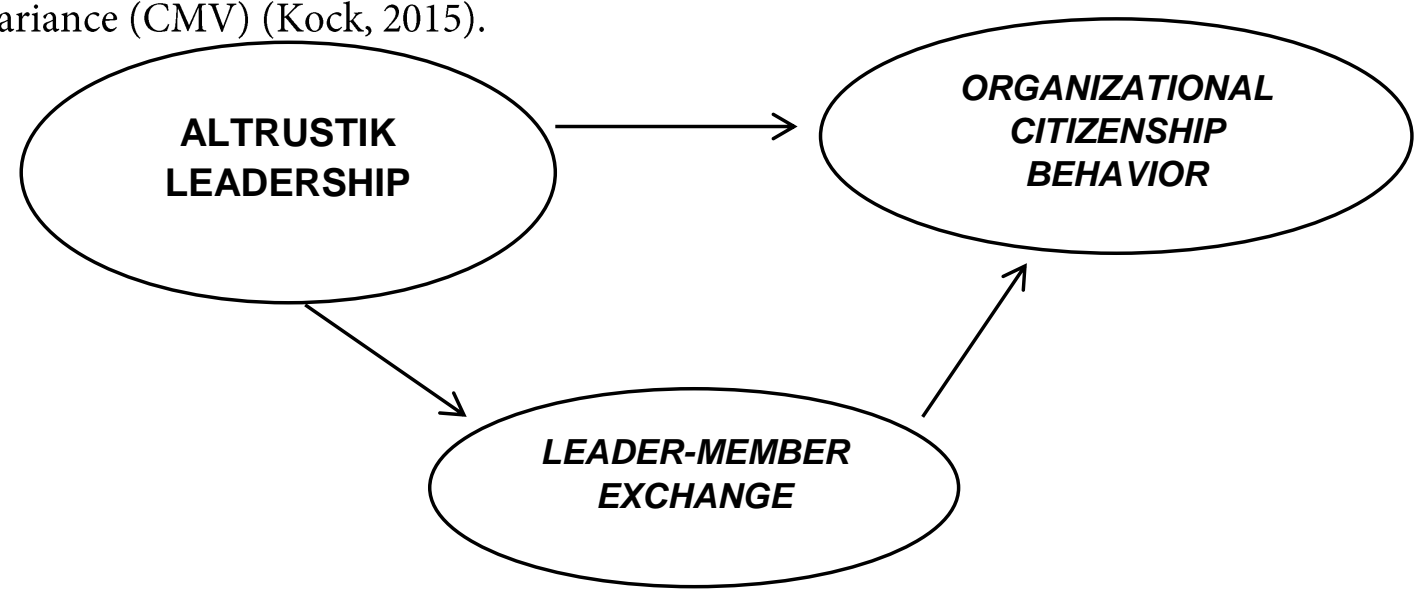

t.s. $=$ not significant, ${ }^{* * *}$ significant at the level 0,001 .

Figure 1. Structural Model: Indirect Effect 


\section{Conclusion}

It can be concluded that altruistic leadership has a positive effect on Leader-member exchange. Leader-member exchange has a negative effect on Organizational citizenship behavior. Leader-member exchange mediates the influence of altruistic leadership on organizational citizenship behavior. From the results of the questionnaire that has been distributed to 203 members of Police Unit in the Pekanbaru city, Leader-member exchange is a variable that must be considered.

With the results obtained are in high intervals, it is recommended to pay attention to the relationship between leaders and subordinates, and also these results are expected to provide innovation and information for leaders to improve relations with subordinates with one goal for the advancement of the office of Police Unit in Pekanbaru city as enforcer of Regional Regulations and Regional Head Regulations.

\section{Acknowledgement}

We thank the anonymous reviewers for their valuable support and guidance in improving the quality of the paper. Furthermore, we thank to Adi Rahmat and Muhammad Rasyid Abdillah for his feedback on earlier versions of the paper. Besides, we also thank Universitas Lancang Kuning, Indonesia, for their assistance and support along the undertaken of this research.

\section{Disclosure statement}

No potential conflict of interest was reported by the authors.

\section{References}

Abdillah, M. R., Lin, C. T., Anita, R., Suroto, B., \& Hadiyati, H. (2018). Knowledge-sharing behavior among banking officers in Indonesia. Journal of International Studies, 11(2), 136-153.

Abdillah, M. R., (2020). Effects of Altruistic Leadership on Knowledge Hiding among Subordinates : Testing a Dual Mediation Mechanism. (Doctoral dissertation, Da-Yeh University, Taiwai).

Abdillah, M. R., Wu,W., Anita, R. (2020). Can Altruistic Leadership Prevent Knowledge-Hiding Behavior? Testing Dual Mediaation Mechanisms. Knowledge Management Research \& Practice.

A.A.Anwar Prabu Mangkunegara. 2011. Manajemen Sumber Daya Manusia Perusahaan. PT.Remaja Rosda Karya, Bandung

Bambang Guritno dan waridin (2005) Guritno,. Pengaruh Persepsi Karyawan Mengenai Perilaku Kepemimpinan, Kepuasan Kerja Dan Motivasi Terhadap Kinerja.JRBI. Vol 1. No 1. Hal: 63-74.

Edy Sutrisno, 2010. Manajemen Sumber Daya Manusia, Edisi Pertama. Cetakan Pertama. Jakarta : Penerbit Kencana

Greenberg, Jerald dan Robert A. Baron. 2003. Behavior in Organization. Prentice Hall. New Jersey.

Kartini Kartono. 2011. Pemimpin dan Kepemimpinan, Jakarta: PT. Rajawali grafindo Persada.

Keith Davis, 2009, Human sBehavior at Work : Organizational Behavior, New York : McGraw-Hill

Miftah Thoha. 2003, Kepemimpinan Dalam Manajemen Jakarta : PT. Raja Grafindo Persada

Miftah Thoha, 2011 Perilaku Organisasi Konsep Dasar dan Aplikasinya, Jakarta : Rajawali Grafindo Persada.

Monge, Peter R and Noshir S. Contractor. 2003. Theories of Communication Networks. Oxford: Oxford University Press.

Organ, D.W., Podsakof, M.P., MacKenzie, B.S. 2006. Organizational Citizenship Behavior. USA : Sage Publications, Inc 
Podsakoff, P.M., Bachrah, D.G \& Bendoly. (2001). Attributions of the causes of group performance as an alternative explanation of the relationship between Organizational Citizenship Behavior and Organizational Performance. Journal of Applied Psychology Vol 6, 1285-1293.

Putri dan Nurul. (2010). Manajemen Sumber Daya Manusia. Bandung: Remaja Rosda Karya.

Rivai, Veithzal dan Deddy Mulyadi, 2003. Kepemimpinan dan Perilaku Organisasi, Raja Grafindo Persada, Jakarta

Robbins dan Judge, 2008, Perilaku Organisasi, Edisi 12, Salemba Empat, Jakarta.

Robbins, Stephen P \& Judge, Timothy A. 2013. Organizational Behavior Edition 15. New Jersey: Pearson Education

Veithzal Rivai, Deddy Mulyadi, 2013. Kepemimpinan dan Perilaku Organisasi, PT. Raja Grafindo Persada, Jakarta.

West, Richard dan Turner, Lynn H. 2009. Pengantar Teori Komunikasi: Analisis dan Aplikasi (Introducing Communication Theory: Analysis and Application). Jakarta: Salemba Humanika.

Zakiy, Muhammad. 2015. Pengaruh Ketidakpastian Psikologis Karyawan Terhadap Kepuasan Kerja dan Intensi Keluar dari Organisasi dengan Leader Member Exchange (LMX) Sebagai Variabel Pemoderasi. Tesis S2 Magister Manajemen Universitas Gajah Mada. 